\title{
Stocking Rate and Fuels Reduction Effects on Beef Cattle Diet Composition and Quality
}

\author{
Abe Clark, ${ }^{1}$ Tim DelCurto, ${ }^{2}$ Martin Vavra, ${ }^{3}$ and Brian L. Dick ${ }^{4}$
}

Authors are ${ }^{1}$ Research Associate and ${ }^{2}$ Program Head \& Director, Eastern Oregon Agriculture and Natural Resource Program, Union Station, Oregon State University, Union, OR 97883, USA; ${ }^{3}$ Emeritis Rangeland Scientist, OSU-EOARC and Starkey Project, and ${ }^{4}$ Starkey Area Manager, USFS, Pacific Northwest Research Station, La Grande, OR 97850, USA.

\begin{abstract}
An experiment was conducted to evaluate the influence of forest fuels reduction on diet quality, botanical composition, relative preference, and foraging efficiency of beef cattle grazing at different stocking rates. A split plot factorial design was used, with whole plots ( 3 ha) being fuel reduced or no treatment (control), and split plots ( 1 ha) within whole plots were grazed to three levels of forage utilization; (low) 3 heifers $\cdot \mathrm{ha}^{-1}$, (moderate) 6 heifers $\cdot \mathrm{ha}^{-1}$, (high) 9 heifers $\cdot \mathrm{ha}^{-1}$, with a 48 -h grazing duration. Grazing treatments were applied in August of 2005 and 2006. Cattle diet composition and masticate samples were collected during 20-min grazing bouts using six ruminally cannulated cows in each experimental unit. Relative preference indices indicated a strong preference for grass regardless of treatment and stocking rate. Grass consumption was lower in control pastures $(P<0.05)$ and tended $(P<0.095)$ to decrease with increased stocking rates. Shrub use was higher in control pastures displaying a quadratic effect $(P<0.05)$ due to stocking, whereas shrub use increased with stocking rate across all treatments. Cattle grazing control pastures consumed diets higher in crude protein compared to cattle grazing treated pastures $(P<0.05)$. In vitro dry matter digestibility values were lower $(P<0.05)$ in control sites and tended $(P=0.10)$ to decrease with increased stocking rates. In both control and treated pastures, bites per minute and grams consumed per minute declined $(P=0.003)$ with increased stocking, indicating foraging efficiency of cattle decreases with increased stocking rates. Our data indicated cattle grazing late season grand fir habitat types have a strong preference for grasses regardless of treatment or stocking rate. However, as stocking rate increased in both control and treated pastures, grass consumption decreased, shrub consumption increased, and foraging efficiency decreased.
\end{abstract}

Key Words: diet quality, diet selection, forage preference, fuels reduction

\section{INTRODUCTION}

Due to increasing concern for and cost of catastrophic wildfires in the Western United States, there is an increasing interest in fuels reduction projects. Fuel reduction treatments utilize various methods of thinning and/or prescribed fire to obtain desirable forest stand conditions (Barbour et al. 2004). However, the effects of fuels reduction on ecosystem function are not well known. Since both public and private timberlands are typically grazed by cattle in the Western United States, it is also important to understand the effect of fuels reduction on cattle diets. Additionally, the interaction of stocking rate and fuels management on forest vegetation diversity and physiological health has not been evaluated in the peer-reviewed scientific literature. This information is not only important for cattle production but also for land management since selective herbivory can have direct and indirect influences on forest communities (Riggs et al. 2005). Herbivores act as a chronic disturbance agent by altering the pathway of succession by

Funding was provided by the Pacific Northwest Research Station, USDA Forest Service Starkey Project, and Eastern Oregon Agriculture and Natural Resource Program, Union Station.

Correspondence: Tim DelCurto, Eastern Oregon Agriculture and Natural Resource Program, Union Station, Oregon State University, Union, OR 97883, USA. Email: tim. delcurto@oregonstate.edu

Current address: Abe Clark, Natural Resource Conservation Service, MLRA Soil Survey Office, 420 Barrett St, Dillon, MT 59725, USA.

Manuscript received 5 September 2012; manuscript accepted 18 July 2013.

(c) 2013 The Society for Range Management accelerating seral vegetation to climax or altering the vegetation present at climax (Hobbs 1996; Riggs et al. 2000). Grazed plants are put at a competitive disadvantage to nongrazed plants, which generally results in a change in plant community composition along with a reduction in overall plant production and/or overall plant nutritive quality (Walker 1995). To explore the effects of fuel reduction and understory burning on vegetation diversity, a series of studies has been developed. This study was designed to test the hypothesis that fuel reduction and understory burning changes understory vegetation diversity, and, in turn, will change diet botanical composition, forage preference, diet quality, and foraging efficiency of cattle grazing at different stocking rates in mixed conifer forests.

\section{MATERIALS AND METHODS}

\section{Study Area}

The study was conducted at the Starkey Experimental Forest and Range located approximately $50 \mathrm{~km}$ southwest of $\mathrm{La}$ Grande, Oregon. The elevation of the study area ranges between $1200 \mathrm{~m}$ and $1500 \mathrm{~m}$. Average annual precipitation is approximately $400 \mathrm{~mm}$ (Bureau of Reclamation AgriMet 2007). Common forest plant associations are in the grand fir (Abies grandis), Douglas-fir (Pseudotsuga menziesii), and ponderosa pine (Pinus ponderosa) series (Johnson and Clausnitzer 1992). This study was conducted in stands of the grand fir series. The dominant grasses include pinegrass (Calama- 
grostis rubescens), western fescue (Festuca occidentalis), Kentucky bluegrass (Poa pratensis), elk sedge (Carex geyeri), California brome (Bromus carinatus), and Idaho fescue (Festuca idahoensis). Common snowberry (Symphoricarpos albus), shinyleaf spiraea (Spiraea betulifolia lucida), twinflower (Linnaea borealis), bearberry (Arctostaphylos uva-ursi), big huckleberry (Vaccinium membranaceum), and grouse huckleberry (Vaccinium scoparium) are the primary shrub species that are found in the study area. The most common forbs include western yarrow (Achillea millefolium), tall annual willowherb (Epilobium paniculatum), strawberry (Fragaria spp.), and lupine (Lupinus spp.).

Stands were thinned with a feller-buncher to reduce fuel loads to no more than 13500 to $18000 \mathrm{~kg} \cdot \mathrm{ha}^{-1}$ (Vavra et al. 2005). The objective was to retain $18.4 \mathrm{~m}^{2} \cdot \mathrm{ha}^{-1}$ basal area of live trees, and live green trees larger than $51 \mathrm{~cm}$ diameter at breast height were not removed (Bull et al. 2005). Stands were ignited by hand with drip torches, and burning occurred when the maximum daily temperature was between $12^{\circ} \mathrm{C}$ and $24^{\circ} \mathrm{C}$, and minimum relative humidity was $15 \%$ to $55 \%$ with the percentage of fuel moisture of 1-h fuels between 4 and 11, of 10-h fuels between 7 and 9, and of 1000-h fuels between 11 and 15 (Bull et al. 2005). In the summer of 2002, two (3-ha) exclosures were constructed in stands treated with mechanical tree removal (summer, 2001) and broadcast burning (fall, 2001). Locations of treated exclosures were established at random within available treated habitat types. These exclosures were built using 8-foot high game fence to ensure no large herbivores would be allowed to graze the exclosures prior to initiation of grazing treatments. Two (3-ha) untreated (control) exclosures were built using electric fence in previously logged mixed conifer forest stands, which are currently grazed. These untreated exclosures were constructed early in the summers of 2005 and 2006 prior to cattle grazing each year. The locations of the untreated exclosures were selected on sites adjacent to the treated exclosures. Within each 3-ha exclosure, three experimental units (1-ha paddocks) were constructed. Each unit was randomly assigned one of three levels of cattle grazing (light, moderate, or heavy stocking). Stocking rate was determined by dividing the estimated biomass of palatable forage in each 1-ha unit (approximately $450 \mathrm{~kg}$ ) by forage consumed per animal per day. The average production in treated pastures was 968 $\mathrm{kg} \cdot \mathrm{ha}^{-1}$ with $371 \mathrm{~kg} \cdot \mathrm{ha}^{-1}$ grass, $360 \mathrm{~kg} \cdot \mathrm{ha}^{-1}$ forb, and 236 $\mathrm{kg} \cdot \mathrm{ha}^{-1}$ shrub production. Three, six, and nine Angus crossbred cows were assigned to a replicate pasture in each treatment and grazed for two full days to approximate 17\% (light), 34\% (moderate), or $51 \%$ (heavy) utilization, respectively. Posttreatment utilization estimates were obtained by means of ocular estimates (60 per ha) similar to that described by Parsons et al. (2003) using regression to adjust for observer error. Grazing treatments were applied in August of 2005 and 2006. The month of August was selected with the assumption that senescence of herbaceous vegetation at that time increased selection of vulnerable shrubs and deciduous trees, e.g., aspen (Populus tremuloides).

Heifers were preconditioned to the area for $2 \mathrm{~d}$ before grazing treatments began each year to account for the effect of previous experience on diet preference (Parsons et al. 1994). For preconditioning, heifers were placed in a holding pasture with similar overstory and understory characteristics as the untreated paddocks. Cattle dietary composition and quality of diet were two of the response variables that were measured in regard to the treatment and level of herbivory. The order in which exclosures were sampled was randomly selected for the first year, and exclosures were visited in the reverse order the second year.

\section{Diet Composition}

Data were collected on species frequency in mid-July, prior to initiation of grazing treatments. Vegetation was sampled along parallel transects located at $15-\mathrm{m}$ intervals within each experimental unit. Ten by ten centimeter square quadrats ( $n=30$ per experimental unit) were located every $10 \mathrm{~m}$ along each transect to measure plant frequency. Frequency was measured by recording presence or absence of species within each plot. This information was used to determine relative preference of species consumed by cattle in each treatment. In mid-August, six ruminally cannulated Angus crossbred cows were used in each experimental unit to estimate nutrient and botanical composition of diets. Botanical composition was determined using bite-count methodology similar to that described by Wickstrom et al. (1984) and Canon et al. (1987). Bite-count data were collected at the initiation of the grazing treatments (entry) and after the grazing treatment. For the bite count estimates at pasture entry, the ruminally cannulated cows (two per pasture) were used across all three stocking rates. At the end of the stocking rate grazing period, all six cows grazed each grazing treatment, with 20-min grazing bouts per animal per treatment. Each observer was assigned a cow at random for each grazing bout. The animals were accustomed to observers in close proximity, and observers had prior training in plant identification. Observers used a small hand-held tape recorder to record the number of bites of each plant species consumed (Findholt et al. 2005). Relative preference was calculated for grasses, shrubs, and forbs by dividing percent bites consumed by percent of plant frequency in the pasture. In order to use frequency data for an estimate of vegetation composition, we divided the frequency of an individual species by the sum of all the vegetation frequencies. This analytical approach has been used in other procedures (Holechek and Gross 1982; Walburger et al. 2007). However, this analytical approach assumes that frequency measurements are equivalent to weight estimates by species, and, as a result, may overestimate species that have a significant cover canopy yet lack production weight (shrubs and some forbs).

\section{Diet Quality}

Cattle diet quality samples were collected in mid-August from six ruminally cannulated cows in each experimental unit (1 ha paddock). Collections occurred in each unit after the grazing treatment was applied. Each cow's ruminal contents were evacuated and the ruminal wall washed with a sponge to remove remaining digesta and ruminal fluid. Cows were allowed to graze for $20 \mathrm{~min}$, and diet samples were obtained via the ruminal cannula. One rumen evacuation per cow was performed in each experimental unit. Ruminal samples were dried in a forced-air oven $\left(55^{\circ} \mathrm{C} ; 96 \mathrm{~h}\right)$ and ground to pass a 1 $\mathrm{mm}$ screen in a Wiley mill. Rumen samples were analyzed in 
Table 1. Percent diet composition by forage class of cattle grazing at entry and after stocking rates of low, moderate, and high were applied to control and treated pastures at the Starkey Experimental Forest and Range, northeast Oregon (data averaged over 2005 and 2006).

\begin{tabular}{|c|c|c|c|c|c|c|c|c|c|}
\hline & \multicolumn{4}{|c|}{ Control } & \multicolumn{5}{|c|}{ Fuels treated } \\
\hline & Entry & Low & Moderate & High & Entry & Low & Moderate & High & SE \\
\hline$\%$ Grass $^{1,2}$ & 68.8 & 74.1 & 80.1 & 56.5 & 82.0 & 86.5 & 83.9 & 81.9 & 7.2 \\
\hline$\%$ Shrub $1,3,4,5$ & 6.1 & 3.5 & 6.2 & 23.5 & 2.6 & 2.2 & 4.5 & 5.4 & 3.5 \\
\hline$\%$ Forb & 25.1 & 22.4 & 13.6 & 17.2 & 15.3 & 11.1 & 11.5 & 13.3 & 7.2 \\
\hline
\end{tabular}

${ }^{1}$ Main effect $(P<0.05)$.

${ }^{2}$ Tendency for quadratic effect due to stocking rate $(P<0.095)$.

${ }^{3}$ Linear effect due to stocking rate $(P=0.008)$

${ }^{4}$ Quadratic effect $(P<0.05)$.

${ }^{5}$ Tendency for quadratic interaction $(P=0.08)$.

duplicate for organic matter, in vitro digestibility (Ankom Daisy II incubator, Ankom Co, Fairport, NY), nitrogen (Leco CN-2000; Leco Corporation, St. Joseph, MI), and neutral detergent fiber (NDF) and acid detergent fiber (ADF; Ankom 200 Fiber Analyzer, Ankom Co). For in vitro dry matter digestibility (IVDMD) determination, rumen fluid was obtained from two ruminally cannulated steers (average $560 \mathrm{~kg}$ ) that were on $100 \%$ forage base diets.

\section{Foraging Efficiency}

Clipped and hand plucked samples were collected from the major forage species consumed during grazing bouts in each main plot. Approximately 50 to 100 simulated bites were collected for each species. Simulated bite size was used to correct botanical composition estimates to account for variation in bite size due to forage type. Samples were placed in paper bags, weighed, dried in a forced air oven at $55^{\circ} \mathrm{C}$, and reweighed to determine dry matter. Samples were then ground to pass a 1-mm screen in a Wiley mill and analyzed for diet quality using the same methods previously described.

Masticate samples were collected from rumen evacuation after each 20-min bout. Samples were dried in a forced air oven at $50^{\circ} \mathrm{C}$. The dried weight was divided by 20 to determine grams consumed per minute. Bites per minute were calculated by dividing the total number of bites per grazing bout by 20 .

\section{Statistical Analysis}

All data were analyzed as a split plot design within a randomized complete block design with two replications over $2 \mathrm{yr}$ using GLM procedures of SAS (SAS Institute, Inc 2005). Year did not have a significant effect nor interact with whole plot (fuels reduction) or subplot (grazing treatment) variables $(P>0.10)$. As a result, year was dropped from the statistical model. Individual paddock was considered the experimental unit. Predetermined contrast statements (Steel et. al 1997) were used to determine significant differences. Contrast statements were as follows: Control vs. Fuels Treated; Linear, Quadratic effects due to stocking rate; Linear Interaction, and Quadratic Interaction for the interaction of fuels reduction and stocking rate for both diet composition and quality. Differences were considered significant at $P<0.05$.

\section{RESULTS AND DISCUSSION}

\section{Diet Composition}

Diet composition by forage class is presented in Table 1 . Grasses made up the greatest proportion of all cattle diets, coinciding with other regional studies by Miller and Krueger (1976), Holechek et al. (1982a), and Walburger et al. (2007). Grass consumption was lower in the control pastures $(P<0.05)$ and tended $(P=0.095)$ to decrease with increased stocking rates. Shrub use was higher in control pastures $(P<0.05)$ with a quadratic effect $(P<0.05)$ due to stocking rate where shrub use tended to increase with increased stocking rate across both treatments. Higher shrub consumption in the control, as well as the overall increase in shrub consumption with higher stocking rates, may be related to the availability of grasses within the pasture (Holechek et al. 1982a). In the control pastures, grass availability may have been limited due to the presence of down logs that restricted cattle movement and made portions of the pastures unavailable. Rosiere et al. (1975) observed an increase is shrub consumption when grass was unavailable.

Grasses were preferred to forbs and shrubs across all treatments as determined using a relative preference index (RPI; Table 2). RPI values indicate a strong preference for grasses regardless of treatment and stocking rate. Forbs and shrubs were never preferred as a forage class in any treatment, although there was a slight increase in shrub use with an increase in stocking rate. Table 2 shows relative preference of the dominant shrub species consumed. Although cattle never preferred shrubs as a forage class, there were individual shrub species that were preferred, including snowberry and shinyleaf spiraea. Snowberry and shinyleaf spiraea were also the dominant shrubs consumed in a study by Holechek et al. (1982a). Pinegrass was the dominant grass occurring across all treatments and was preferred in each treatment, with the exception of entry control (Table 2). Pinegrass RPI was higher in the fuels treated pastures. McLean (1983) reported that in Canada, pinegrass growing under shade was less palatable than that under open canopies. Elk sedge and Kentucky bluegrass were highly preferred in every treatment, while timothy (Phleum pratense) and tall trisetum (Trisetum canescens) were preferred in the control pastures. Holechek et al. (1982a) also suggested that elk sedge was a preferred species, based on consumption and cover, in a study identifying important dietary constituents of cattle at the Starkey Experimental Forest and Range. Clark (2003) suggested that since elk sedge maintains at least moderate forage quality throughout the year it may help sustain herbivore diet quality when other forage species reach senescence.

\section{Diet Quality}

Diet quality in terms of crude protein (CP), NDF, ADF, and IVDMD is presented in Table 3. CP values of masticate samples were higher $(P<0.05)$ in control sites than fuelstreated sites. Cattle grazing control pastures had an average $\mathrm{CP}$ value of $9.4 \%$ compared with $8.5 \% \mathrm{CP}$ in treated pastures. The National Research Council suggests mature lactating beef cattle (545 kg; National Research Council 1996) should 
Table 2. Relative preference index (RPI; composition of diet divided by the estimate of composition of available vegetation) by forage class and dominant grasses and shrubs consumed by cattle grazing at entry in the pastures and after low, moderate, and high stocking rates were applied to control and treated pastures at the Starkey Experimental Forest and Range, northeast Oregon (data averaged over 2005 and 2006).

\begin{tabular}{|c|c|c|c|c|c|c|c|c|}
\hline & \multicolumn{4}{|c|}{ Control } & \multicolumn{4}{|c|}{ Fuels treated } \\
\hline & Entry & Low & Moderate & High & Entry & Low & Moderate & High SE \\
\hline RPI Grass ${ }^{1,2}$ & 2.5 & 3.0 & 2.5 & 2.1 & 4.3 & 6.1 & 3.5 & $\begin{array}{ll}3.7 & 0.4\end{array}$ \\
\hline California brome ${ }^{3}$ & 8.7 & 1.5 & 1.5 & 1.2 & 7.0 & 3.6 & 1.6 & 7.31 .2 \\
\hline Elk sedge & 4.4 & 18.6 & 16.5 & 7.8 & 4.8 & 28.8 & 6.8 & 21.68 .1 \\
\hline Pinegrass & 0.7 & 6.3 & 3.7 & 1.8 & 4.6 & 13.3 & 5.2 & 10.73 .4 \\
\hline Orchardgrass & 3.2 & 0.6 & 0.1 & 0.9 & 0.1 & 0.0 & 0.6 & 0.00 .4 \\
\hline Idaho fescue & 1.8 & 1.9 & 0.5 & 1.2 & 0.5 & 0.2 & 1.3 & 1.20 .9 \\
\hline Western fescue & 0.6 & 0.7 & 1.0 & 2.4 & 0.4 & 0.3 & 0.5 & 0.80 .8 \\
\hline Timothy $^{1}$ & 4.0 & 2.6 & 2.4 & 1.3 & 0.7 & 0.1 & 0.0 & 0.81 .0 \\
\hline Kentucky bluegrass ${ }^{4}$ & 19.0 & 12.7 & 8.4 & 19.1 & 19.8 & 5.8 & 1.9 & 5.83 .3 \\
\hline Tall trisetum & 1.8 & 1.5 & 2.0 & 0.8 & 0.6 & 0.1 & 0.1 & 0.00 .9 \\
\hline RPI Shrub ${ }^{1}$ & 0.2 & 0.2 & 0.2 & 0.8 & 0.5 & 0.9 & 0.7 & 0.50 .2 \\
\hline Bearberry & 0.1 & 0.2 & 0.2 & 0.2 & 0.0 & 0.1 & 0.1 & 0.40 .2 \\
\hline Twinflower & 0.1 & 0.1 & 0.5 & 0.1 & 0.0 & 0.0 & 0.1 & 0.00 .1 \\
\hline Oregon grape ${ }^{3}$ & 0.1 & 0.1 & 0.9 & 3.1 & 0.5 & 0.3 & 0.2 & 0.20 .7 \\
\hline Rose & 0.6 & 1.1 & 0.6 & 1.6 & 0.0 & 0.3 & 0.1 & 0.70 .7 \\
\hline Shinyleaf spiraea & 0.5 & 4.3 & 2.3 & 1.7 & 0.6 & 0.1 & 0.2 & 0.11 .8 \\
\hline Snowberry & 2.5 & 1.4 & 4.9 & 11.1 & 2.3 & 4.3 & 2.4 & 4.33 .6 \\
\hline Grouse huckleberry & 0.1 & 0.3 & 0.4 & 0.3 & 0.0 & 0.1 & 0.0 & 0.00 .1 \\
\hline Big huckleberry & 0.2 & 0.4 & 1.1 & 2.6 & 0.0 & 0.0 & 0.0 & 0.01 .0 \\
\hline RPI Forb ${ }^{1}$ & 0.6 & 0.4 & 0.3 & 0.4 & 0.2 & 0.1 & 0.2 & 0.20 .1 \\
\hline
\end{tabular}

${ }^{1}$ Main effect $(P<0.05)$.

${ }^{2}$ Quadratic effect due to stocking rate $(P<0.05)$

${ }^{3}$ Linear interaction $(P<0.05)$.

${ }^{4}$ Linear effect due to stocking rate $(P<0.05)$.

consume $9.25 \% \mathrm{CP}$ in their diets in order meet CP requirements. Therefore, cattle grazing treated pastures may be faced with diets that are marginally deficient in protein content. Higher $\mathrm{CP}$ values in the control diets may be attributed to higher shrub consumption in those pastures. Holechek and Vavra (1983) suggested that shrubs retain higher CP levels than grasses and forbs in late summer. No differences in CP were found between stocking rates within control or treated pastures. Likewise, no differences were found in ADF or NDF values. However, there was a tendency for a linear effect due to stocking rate $(P=0.14)$ for NDF values. Diet NDF values appeared to increase with increased stocking rates in both control and treated sites. IVDMD values were lower $(P<0.05)$ in control sites and tended $(P=0.10)$ to decrease with increased stocking rates. Lower IVDMD values in the control pastures and the tendency for IVDMD values to decrease with increased stocking rate is likely due to a greater percent of shrubs in the diet. This relationship contradicts the high IVDMD values of hand plucked shrub samples (Table 4). However, difficulties in collecting representative shrub bites may have produced observer bias. Cattle likely consumed woodier, less digestible, portions of the shrubs than observers collected from hand plucking. Generally, it has been assumed that cattle select higher quality diets than can be clipped (Lesperance et al.
Table 3. Percent crude protein (CP), neutral detergent fiber (NDF), acid detergent fiber (ADF), and in vitro dry matter digestibility (IVDMD) of masticate samples from cattle grazing at low, moderate, and high stocking rates in control and treated pastures at the Starkey Experimental Forest and Range, northeast Oregon (data averaged over 2005 and 2006).

\begin{tabular}{lrrrrrrrr}
\hline & \multicolumn{3}{c}{ Control } & & \multicolumn{4}{c}{ Fuels treated } \\
\cline { 2 - 3 } \cline { 8 - 9 } & Low & Moderate & High & & Low & Moderate & High & SE \\
\hline CP $^{1}$ & 9.3 & 9.3 & 9.7 & & 8.5 & 8.8 & 8.3 & 0.32 \\
NDF $^{2}$ & 66.8 & 66.7 & 69.2 & & 66.9 & 66.6 & 67.2 & 0.87 \\
ADF & 42.5 & 42.6 & 42.3 & & 42.3 & 42.8 & 43.1 & 0.97 \\
IVDMD $^{1,3}$ & 64.3 & 62.7 & 58.9 & & 65.3 & 66.1 & 65.2 & 1.5 \\
\hline
\end{tabular}

${ }^{1}$ Main effect $(P<0.05)$

${ }^{2}$ Tendency for linear effect due to stocking rate $(P=0.14)$.

${ }^{3}$ Tendency for quadratic interaction $(P=0.10)$.

1960). Individuals estimating diet quality from hand plucked samples where shrubs are a significant diet component should be aware of this discrepancy.

Overall, grasses and forbs in control pastures had greater nutritive values than grasses and forbs in treated pastures, while shrubs were similar in nutritive value (Table 4). In both control and treated pastures, grasses had lower average CP than forbs and shrubs. Grasses in control pastures had higher average CP levels $(6.5 \%)$ than grasses in treated pastures $(4.9 \%)$, and $\mathrm{CP}$ values were always higher in control pastures than treated pastures when the same species were collected. Forb CP levels were higher in the control pastures when the same species was collected, and average forb CP was also higher in the control pastures $(12.8 \%$ CP compared to $8.1 \%$ $\mathrm{CP}$, respectively). Shrub CP was similar with slightly higher levels in the treated pastures as compared to control pastures (8.8 compared to 8.4, respectively). Average grass and forb ADF, IVDMD, and percent moisture levels were higher and $\mathrm{NDF}$ values were lower in control pastures compared to treated pastures. The higher percent moisture and nutritive value in forage found in the control pastures may be due to differences in the growth stage of the forage present (Skovlin 1967; Cruz and Ganskopp 1998; Perez Corona et al. 1998). Growth stage may also explain the similarity in nutritive quality and moisture levels in shrubs since shrubs tend to reach senescence later in the year than forbs and grasses (Ganskopp et al. 1999). The earlier senescence of forbs and grasses in the treated pastures may be due to the decrease in the forest canopy cover and the reduction of course woody debris, which in turn alters available soil water and soil temperature of the site (Svejcar and Vavra 1985; Kruger and Bedunah 1988). Accelerated plant phenology due to a decrease in canopy cover was also reported by Long et al. (2008a) in a study at the Starkey Experimental Forest and Range looking at the effects of fuels reduction on the quantity and quality of forage for elk.

\section{Foraging Efficiency}

Foraging efficiency of cattle decreased with increased stocking rates in both control and fuels treated sites (Fig. 1). Grams consumed per minute decreased in both control and treated pastures as stocking rate increased $(P=0.003)$. Stocking rate also had a similar linear effect $(P=0.003)$ on bites consumed per minute (Fig. 2), with a decrease in bites per minute with 
Table 4. Percent crude protein (CP), neutral detergent fiber (NDF), acid detergent fiber (ADF), in vitro dry matter digestibility (IVDMD), and percent moisture of hand plucked forages by species in control and treated pastures at the Starkey Experimental Forest and Range, northeast Oregon (data averaged over 2005 and 2006).

\begin{tabular}{|c|c|c|c|c|c|c|c|c|c|c|}
\hline \multirow[b]{2}{*}{ Forage species } & \multicolumn{5}{|c|}{ Control } & \multicolumn{5}{|c|}{ Fuels treated } \\
\hline & $\mathrm{CP}$ & NDF & ADF & IVDMD & $\begin{array}{c}\% \\
\text { Moisture }\end{array}$ & $\mathrm{CP}$ & NDF & ADF & IVDMD & $\begin{array}{c}\% \\
\text { Moisture }\end{array}$ \\
\hline \multicolumn{11}{|l|}{ Grasses } \\
\hline California brome & 8.8 & 60.4 & 34.1 & 68.0 & 53.1 & 4.1 & 72.9 & 44.4 & 51.8 & 16.0 \\
\hline Elk sedge & 6.4 & 65.3 & 35.7 & 62.9 & 31.3 & 5.7 & 65.6 & 36.7 & 63.3 & 29.4 \\
\hline Pinegrass & 9.4 & 60.3 & 33.4 & 66.3 & 49.1 & 6.9 & 59.6 & 35.0 & 61.5 & 23.0 \\
\hline Western fescue & 4.0 & 71.3 & 41.2 & 49.9 & 6.7 & 3.6 & 79.7 & 48.6 & 36.0 & 7.8 \\
\hline Timothy & 4.7 & 65.1 & 37.0 & 54.3 & 44.4 & 3.9 & 65.8 & 36.3 & 56.4 & 24.5 \\
\hline Kentucky bluegrass & 7.0 & 64.4 & 36.0 & 59.5 & 36.6 & 5.7 & 64.8 & 36.6 & 61.8 & 21.8 \\
\hline \multicolumn{11}{|l|}{ Forbs } \\
\hline Western yarrow & & & & & & 6.6 & 45.5 & 33.8 & 69.0 & 9.7 \\
\hline Lupine & 10.6 & 30.5 & 21.4 & 84.6 & 47.3 & 10.9 & 36.8 & 25.2 & 75.4 & 13.9 \\
\hline White clover & 14.5 & 40.5 & 28.8 & 74.8 & 48.7 & 11.5 & 47.5 & 35.9 & 65.9 & 38.3 \\
\hline \multicolumn{11}{|l|}{ Shrubs } \\
\hline Rose & 8.6 & 37.1 & 18.1 & 82.6 & 22.2 & 9.1 & 30.3 & 15.2 & 79.9 & 22.7 \\
\hline Shinyleaf spiraea & 8.0 & 37.2 & 22.8 & 72.5 & 12.0 & 8.4 & 32.2 & 19.3 & 81.0 & 22.2 \\
\hline Snowberry & 9.2 & 26.3 & 17.7 & 81.3 & 28.1 & 9.0 & 26.5 & 16.9 & 82.8 & 39.7 \\
\hline
\end{tabular}

increased stocking rate for both control and treated pastures. There were no significant differences between control and treated pastures.

Foraging efficiency may have had an influence on the relationship between stocking rates and utilization. The anticipated percent utilization for low, moderate, and high stocked pastures were $17 \%, 34 \%$, and $51 \%$, respectively; however, average utilization estimates were $26 \%, 31 \%$, and $35 \%$ for low, moderate, and high pastures, respectively. Low pastures were on average grazed $10 \%$ heavier than predicated.

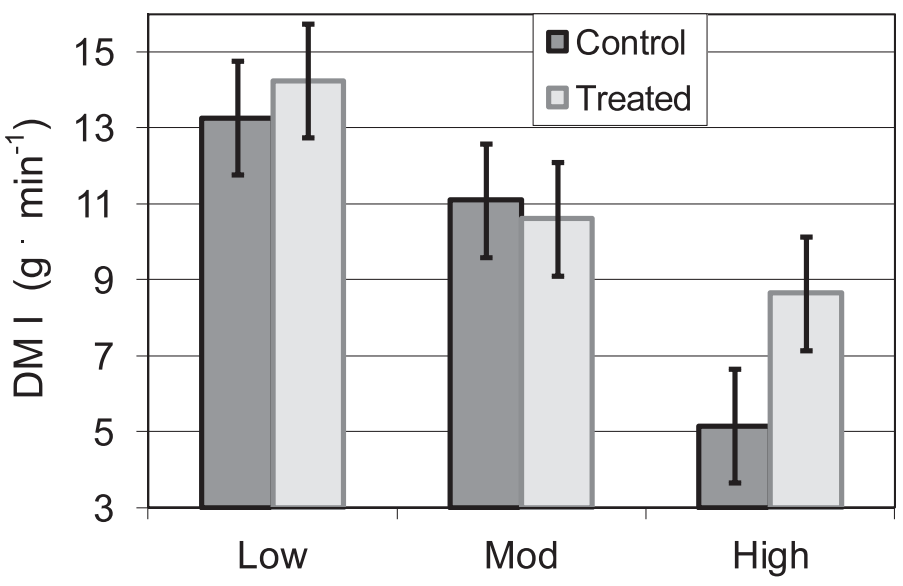

\section{Stocking Rate}

Figure 1. Grams dry matter consumed $\cdot \mathrm{min}^{-1}$ of cattle grazing at low, moderate, and high stocking rates in control and treated pastures at the Starkey Experimental Forest and Range, northeast Oregon (data averaged over 2005 and 2006). Grams consumed $\cdot \mathrm{min}^{-1}$ decreased in both control and treated pastures as stocking rate increased $(P=0.003$; pooled $\mathrm{SE}=1.68, n=4)$.
Moderate pastures were grazed to the approximate goal of $34 \%$ utilization. While high pastures were grazed $15 \%$ less than predicted.

\section{MANAGEMENT IMPLICATIONS}

Cattle grazing late season grand fir habitat types have a strong preference for grass regardless of treatment or stocking rate. In our study, fuel reduction did not cause an increase in late summer/early fall shrub consumption or preference. Cattle did show an increase in shrub use as stocking rate increased; however, cattle never showed an overall preference for shrubs. The increase in shrub use seemed to be a function of grass availability. Snowberry in both the control and treated pastures and spiraea in the control pastures were preferred species, therefore emphasizing the importance of balancing grazing pressure with plant species tolerance in order to prevent unwanted changes in plant community composition. Cattle in our study did not select forage based solely on the nutritional quality of the plant species. Of the dominant forages consumed, cattle showed the strongest preference for elk sedge. The preference for elk sedge in late summer/early fall could possibly be due in part to its evergreen characteristics or nutrient density per bite.

The apparent acceleration of plant phenology in fuels-treated sites may have a negative effect on late season grass and forb nutritive quality and could lower $\mathrm{CP}$ availability for cattle grazing in late summer/early fall. Managers may find protein supplementation to be a valid option for compensating for lower available CP in fuel reduced and understory burned stands. Managers may also consider grazing fuels treated sites earlier in the year before grasses and forbs senesce or implementing fuels reduction in a portion of the stands to provide cattle with increased early season forage while 


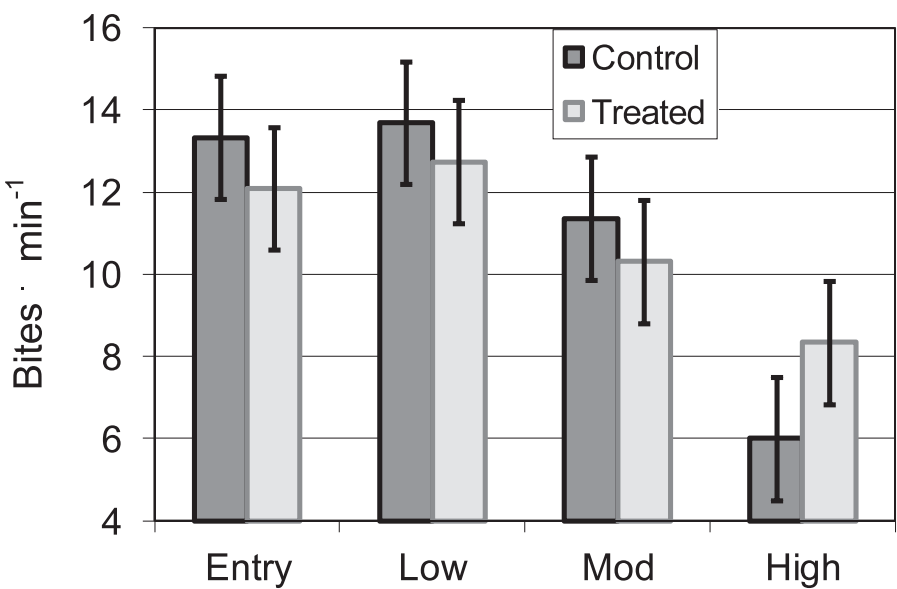

Stocking Rate

Figure 2. Bites consumed $\cdot \mathrm{min}^{-1}$ of cattle grazing at pasture entry (within first $4 \mathrm{~h}$ of pasture grazing) and at the end of grazing period for low, moderate, and high stocking rates in control and treated pastures at the Starkey Experimental Forest and Range, northeast Oregon (data averaged over 2005 and 2006). Bites consumed $\cdot \mathrm{min}^{-1}$ decreased in both control and treated pastures as stocking rate increased $(P=0.003$; pooled $\mathrm{SE}=1.55, n=4)$.

retaining higher quality late season forage in the untreated portion. Long et al. (2008b), working on the same landscape, suggested maintaining a mixture of fuels treated and untreated stands to provide better long-term foraging opportunities for mule deer (Odocoileus hemionus) and elk (Cervus elaphus). Fuels reduction occurs in many other plant communities and forest types. Season of use and stocking rates are variable within and across these habitat types. As a result, further research is needed to better understand the effects of fuels reduction on forage quantity and quality, and to develop proper stocking rates that coincide with season of use across various fuels treated stands.

\section{ACKNOWLEDGMENTS}

Appreciation is also extended to Starkey Project employees Ryan Kennedy, Dennis Rae, Jack Nothwang, Kristen Mundy, and Bridgett Neylor; Union Station employees Daalkhaijav Damiran, Enkhjargal Darambazar, Kenny Fite, Mark Fite, Ken Walburger, and C. W. Dunbar for assistance in data collection; and Jana Lee Dick for formatting and reviewing.

\section{LITERATURE CITED}

Barbour, R. J., R. D. Fight, G. A. Christensen, G. L. Pinjuv, and R. V. Nagubadi. 2004. Thinning and prescribed fire and projected trends in wood product potential, financial return, and fire hazard in Montana. Portland, OR, USA: USDA Forest Service, Pacific Northwest Research Station. General Technical Report PNWGTR-606. 78 p.

Bull, E. L., A. A. ClaRk, and J. F. Shepherd. 2005. Short-term effects of fuel reduction on pileated woodpeckers in northeastern Oregon: a pilot study. Portland, OR, USA: USDA Forest Service, Pacific Northwest Research Station. Research Paper PNW-RP-564. 17 p.
Bureau of Reclamation Agrimet. 2007. Pacific Northwest weather data. Available at: http://www.usbr.gov/pn/agrimet. Accessed 7 May 2007.

Canon, S. K., P. J. Urness, and N. V. DeByle. 1987. Habitat selection, foraging behavior, and dietary nutrition of elk in burned aspen forest. Journal of Range Management 40:433-438.

ClaRk, P. E. 2003. Date and plant community effects on elk sedge forage quality. Journal of Range Management 56:21-26.

Cruz, R., and D. Ganskopp. 1998. Seasonal preferences of steers for prominent northern Great Basin grasses. Journal of Range Management 51:557-565.

Findholt, S. L., B. K. Johnson, D. Damiran, T. DelCurto, and J. G. Kie. 2005. Diet composition, dry matter intake, and diet overlap of mule deer, elk, and cattle. In: M. J. Wisdom [ED.]. The Starkey Project: a synthesis of long-term studies of elk and mule deer. Reprinted from Lawrence, KS, USA: 2004 Transactions of the North American Wildlife and Natural Resource Conference, Alliance Communications Group. p. 159-169.

Ganskopp, D., T. Svejcar, F. Taylor, J. Farstvedt, and K. Painter. 1999. Seasonal cattle management in 3 to 5 year old bitterbrush stands. Journal of Range Management $52: 166-173$

HoвBs, N. T. 1996. Modification of ecosystems by ungulates. Journal of Wildlife Management 60:695-713.

HoleCHEK, J. L., AND B. D. Gross. 1982. Evaluation of different calculation procedures for microhistological analysis. Journal of Range Management 35:721-723.

HolecheK, J. L., and M. Vavra. 1983. Drought effects on diet and weight gains of yearling heifers in Northeastern Oregon. Journal of Range Management 36:227231.

Holechek, J. L., M. Vavra, J. Skovin, and W. C. Krueger. 1982. Cattle diets in the Blue Mountains of Oregon. II. Forests. Journal of Range Management 35:239-242.

Johnson, C. G., JR., and R. R. Clausnitzer. 1992. Plant associations of the Blue and Ochoco Mountains. Portland, OR, USA: USDA Forest Service, Pacific Northwest Region, Wallowa-Whitman National Forest. Technical Publication R6-ERW-TP036-92. $164 \mathrm{p}$.

Krueger, J. K., and D. J. Bedunah. 1988. Influence of forest site on total nonstructural carbohydrate levels of pinegrass, elk sedge, and snowberry. Journal of Range Management 41:144-149.

Lesperance, A. L., V. H. Jensen, V. R. Bohman, and R. A. Madsen. 1960. Measuring selective grazing with fistulated steers. Journal of Dairy Science 43:1615-1621.

Long, R. A., J. L. Rachlow, J. G. KIE, and M. Vavra. 2008a. Fuels reduction in a western coniferous forest: effects on quantity and quality of forage for elk. Rangeland Ecology \& Management 61:302-313.

Long, R. A., J. L. RaChlow, And J. G. KIE. 2008b. Effects of season and scale on response of elk and mule deer to habitat manipulation. Journal of Wildlife Management 72:1133-1142.

McLean, A. 1983. Classification and management of the Douglas-fir-pinegrass region. In: B. F. Roche, Jr. and D. M. Baumgartner [EDS.]. Forestland grazing. Pullman, WA, USA: Washington State University. $114 \mathrm{p}$.

Mllter, R. F., And W. C. Krueger. 1976. Cattle use on summer foothill rangelands in northeastern Oregon. Journal of Range Management 29:367-371.

National Research Council. 1996. Nutrient requirements of cattle. Washington, DC, USA: National Academy Press. p. 227.

Parsons, A. J., J. A. Newman, P. D. Penning, A. Harvey, and R. J. Orr. 1994. Diet preference of sheep: effects of recent diet, physiological state, and species abundance. Journal of Animal Ecology 63:465-478.

Parsons, C. T., P. A. Momont, T. DelCurto, M. Mclnnis, and M. L. Porath. 2003. Cattle distribution patterns and vegetation use in mountain riparian areas. Journal of Range Management 56:334-341.

Perez Corona, M. E., B. R. Vazquez de Aldana, B. Garcia Criado, and A. Garcia Ciudad. 1998. Variations in nutritional quality and biomass production of semiarid grasslands. Journal of Range Management 51:570-576.

RigGs, R. A., J. G. Cook, AND L. L. IRWIN. 2005. Management implications of ungulate herbivory in Northwest forest ecosystems. In: M. J. Wisdom [ED.]. The Starkey Project: a synthesis of long-term studies of elk and mule deer. Reprinted from Lawrence, KS, USA: 2004 Transactions of the North American Wildlife and Natural Resource Conference, Alliance Communications Group. p. 217-232.

Riggs, R. A., A. R. Tiedemann, J. G. Cook, T. M. Ballard, P. J. Edgerton, M. Vavra, W. C. Krueger, F. C. Hall, L. D. Bryant, L. L. Irwin, and T. DelCurto. 2000. Modification of mixed-conifer forests by ruminant herbivores in the Blue Mountains Ecological 
Province. La Grande, OR, USA: USDA Forest Service, Pacific Northwest Region. Research Paper PNW-RP-527. $84 \mathrm{p}$.

Rosiere, R. E., R. F. Beck, and J. D. Wallace. 1975. Cattle diets on semidesert grassland: botanical composition. Journal of Range Management 28:89-93.

SAS InstitUTE, INC. [COMPUTER PRoGRAm]. 2005. Statistical analysis systems, version 8. Cary, NC, USA: SAS Institute, Inc.

SkovLIN, J. 1967. Fluctuations in forage quality on summer range in the Blue Mountains. Portland, OR, USA: USDA Forest Service PNW Forest and Range Experiment Station. Research Paper PNW-44. 20 p.

Steel, R. G. D., J. H. TorRie, and D. A. Dickey. 1997. Principles and procedures of statistics: a biometrical approach. 3rd ed. New York, NY, USA: McGraw Hill Book Co. $666 \mathrm{p}$.

Svejcar, T., AND M. VavRa. 1985. The influence of several range improvements on estimated carrying capacity and potential beef production. Journal of Range Management 38:395-399.
Vavra, M., M. J. Wisdom, J. G. Kie, J. G. Cook, and R. A. Riggs. 2005. The role of ungulate herbivory and management of ecosystem patterns and processes: future direction of the Starkey project. In: M. J. Wisdom [ED.]. The Starkey Project: a synthesis of long-term studies of elk and mule deer. Reprinted from Lawrence, KS, USA: 2004 Transactions of the North American Wildlife and Natural Resource Conference, Alliance Communications Group. p. 233-239.

Walburger, K. J., T. DelCurto, and M. Vavra. 2007. Influence of forest management and previous herbivory on cattle diets. Rangeland Ecology \& Management 60:172-178.

WaLKER, J. W. 1995. Viewpoint: grazing management and research now and in the next millennium. Journal of Range Management 48:350-357.

Wickstrom, M. L., C. T. Robiins, T. A. Hanley, D. E. Spalinger, and S. M. Parish. 1984. Food intake and foraging energetics of elk and mule deer. Journal of Wildlife Management 48:1285-1301. 